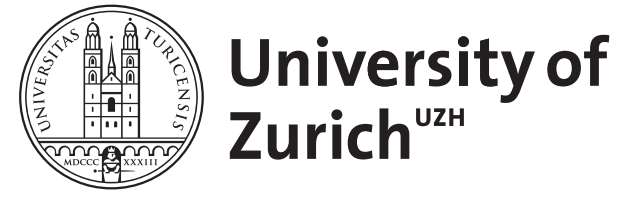

The Literary Growth of the Song of Songs during the Hasmonean and Early-Herodian Periods, written by Torleif Elgvin

Hopf, Matthias Rüdiger

DOI: https://doi.org/10.1163/15700631-12511301

Posted at the Zurich Open Repository and Archive, University of Zurich ZORA URL: https://doi.org/10.5167/uzh-191320

Journal Article

Accepted Version

Originally published at:

Hopf, Matthias Rüdiger (2020). The Literary Growth of the Song of Songs during the Hasmonean and Early-Herodian Periods, written by Torleif Elgvin. Journal for the Study of Judaism, 51:583-591.

DOI: https://doi.org/10.1163/15700631-12511301 


\section{Torleif Elgvin}

The Literary Growth of the Song of Songs During the Hasmonean and Early-Herodian Periods (CBET, 89). Leuven: Peeters, 2018. Pp. xiv + 237. €72. ISBN 9789042935273.

In his work on the Song of Songs, Torleif Elgvin pursues two main goals: First, he presents a whole new edition of the Qumran fragments of the Song (4QCant ${ }^{\mathrm{a}-\mathrm{c}}$ and 6QCant). Second and based on the first, he seeks to establish the hypothesis that the Song has its main roots in the Hasmonean era and underwent an editorial process in the first centuries BCE and CE.

Of the almost 200 text pages, more than a third is dedicated to the Qumran manuscripts that are discussed in chapter 1. Elgvin has personally undertaken a close reexamination of the fragments in Jerusalem, something that sets the study apart from others that are based on the editions in DJD III (6QCant, 1962 by M. Baillet) and XVI (4QCant ${ }^{\mathrm{a}-\mathrm{c}}$, 2000 by E. Tov. ${ }^{1}$ Elgvin also interacts with other proposed reconstructions e. g. by E. Puech. ${ }^{2}$ Each scroll is documented in several steps: After remarks on the physical description, paleography, and orthography, he gives some "notes on readings," in which he presents the discernable markings or letters. Then, he proceeds to a full reconstruction including propositions for the passages in between given textual data, "notes on the reconstruction" (if relevant), comments on the variants, and a translation. As such, it is a full critical edition made from scratch with references to every major witness, including LXX, Peshitta etc.

The major strength of the text-critical chapter lies in the plain readings of the manuscripts. In those passages, Elgvin proceeds very carefully, and circumspectly. However, this changes somewhat in his reconstructions and interpretations, in which he sometimes takes a very bold approach; at points,

\footnotetext{
${ }^{1}$ Or the prior publication by Tov in JJS 46 (1995): 88-111.

${ }^{2}$ E. Puech, "Le Cantique des Cantiques dans les manuscrits de Qumran," RB 123 (2016): $29-53$.
} 
he includes conjecturing textual changes, some of which are open to scrutiny. Still, his use of rather recent photographic material not available at the time of the first editions, as well as of microscopic techniques is highly commendable. In fact, it enables him to identify a couple of readings that differ from Baillet's and Tov's reconstructions. Not every detail of Elgvin's readings can be discussed in this review. Still, as this chapter represents a major contribution to Song of Songs scholarship, I would like to present more than only a short roundup:

With respect to 4QCant ${ }^{\mathrm{a}}$ the following findings are most noteworthy. He dates the scroll to the early first century CE (vis-à-vis Tov's early Herodian period); the manuscript is characterized as a pre-masoretic recension; the placing of fragment 1 is different, changing the line numbers from 9-12 (Tov) to a possible range of 8/10 - 11/13, assuming another three lines under the visible text; he proposes more variant readings (compared with MT) than Tov's reconstruction does, while at the same time suggesting that $4 \mathrm{QCant}{ }^{\mathrm{a}}$ might have contained a shorter text than MT.

One issue with his reconstruction is that the majority of the text does actually not differ much from Tov's. Many of his variant readings (vis-à-vis MT and DJD) are found on the fringes of the fragments, which is why they are, evidently somewhat uncertain. In those cases, he relies on calculated letter spaces in between lines, on a fragmentary stroke of a letter, or the lack thereof. Some seem by all means plausible, but for others one would wish for more

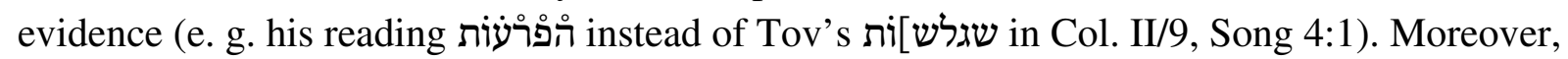
his reconstructions are highly optimistic in that they provide very large portions of text without much data to lean on (e. g. from the small fragment 1 he extrapolates to a reading of around four verses). Lastly, several of his assumed variant readings are based on argumenta $e$ silentio, e. g., he contends that there probably was only one column before the present Col. I instead of two, as he surmises that the scroll might have commenced around Song 2:3. Admittedly, the textual material known from MT is at odds with the space needed for either one or two full columns, which indeed suggests a variant text. Yet, the given data is, in my opinion, too scant to deduce anything specific about the original length of the text.

Elgvin's edition of $4 \mathrm{QCant}{ }^{\mathrm{b}}$ needs the most detailed discussion. For the scroll in general, the major findings are as follows. He proposes a dating to the third quarter of the first century BCE (comp. Tov: early Herodian period), which would make 4QCant ${ }^{\mathrm{b}}$ the "earliest textual witness to Canticles" (64). Also, he characterizes the manuscript as "more than a sloppy copy made for personal use" (62), and sees it as a free and creative rendering by the scribe and 
"Kleinsammlung" (Heinevetter), ${ }^{3}$ i. e., a manuscript containing a deliberate collection of single poems as demonstrated by the recurring vacats (a possible, but not necessary conclusion). Correspondingly, he does not interpret 4QCant ${ }^{\mathrm{b}}$ as an abbreviation since "the shorter text ... flows more rhythmically" (89). Such aesthetic arguments need to be treated very carefully. With reference to wear patterns, Elgvin assumes that the scroll was deposited with its beginning on the inside. Furthermore, there probably was no additional sheet and column before the existent Col. I, at least at the time of the deposition. Thus, 4QCant ${ }^{\mathrm{b}}$ would have commenced with Song 2:9b.

One issue with this latter aspect is that the identified wear pattern b (see fig. 16 on page 33) should probably also be visible on fragment 1 around the left margin of Col. I. The other wear patterns seem not quite as convincing. Nevertheless, it is highly likely that $4 \mathrm{QCant}{ }^{\mathrm{b}}$ featured a variant reading vis-à-vis MT, as the textual material known from the latter would fit in neither one nor two preceding columns. Accordingly, Elgvin's proposal deserves reconsideration.

With respect to Col. I, Elgvin by and large confirms Tov's edition with the following noteworthy aspects. He confirms the existence of a supercolumnar title, which he also invokes to substantiate his claim about the lack of preceding sheets. Still, the title is slightly to the right of the column (see PAM 40.604), which might be somewhat at odds with this assumption. Consequentially, Elgvin needs to propose a different reading of Song 2:9b, as the MT text would not fit. He suggests reading הנה זה דודי משגיח, an interesting notion as this

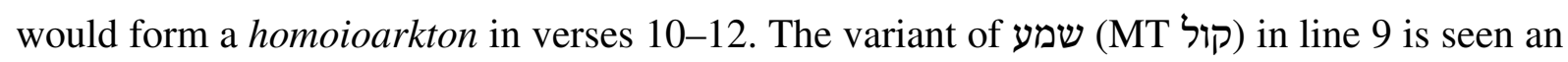
argument for $4 \mathrm{QCant}{ }^{\mathrm{b}}$ being an older literary form than MT, as קול is the "more common term" and "a stylistic attempt to create variation" (40f.). While the former could indeed be an argument for an older provenance, the latter can be more easily explained as a secondary harmonization with the corresponding verb שמע Hi. With regard to the peculiar scribal signs in the margins of Col. I, Elgvin shows that only three of the five signs put forward by Tov do exist, namely those in lines 4, 9, and 11. Finally, he refutes Puech's claim of scribal corrections beneath Col I/15.

The most significant changes compared to Tov's edition are in Col. II: In a completely different reconstruction of the first half of the column, Elgvin identifies: Song 3:2; 3:6 - 4:1 (instead of Tov's Song 3:5; 3:9-4:1, which is itself problematic due to line length). This is based on different readings of the few

\footnotetext{
${ }^{3}$ H.-J. Heinevetter, “Komm nun, mein Liebster, dein Garten ruft dich!”: Das Hohelied als programmatische Komposition, Bonner Biblische Beiträge 69 (Frankfurt a. M.: Atenäum, 1989).
} 
letters in lines 3 and 5 (Elgvin's count, which is unfortunately a little confusing in this chapter). Another major change can be seen at the end of Elgvin's line 13, and consequentially in the latter lines of Col. II - a reconstruction that seems more plausible than that by Tov and Puech (cf. photograph B-295453).

The major problem with Col. II, though, is that not much is legible. Elgvin's reading is certainly a possibility, but one should be cautious with any reconstruction of this passage. In the proposed one, the tendency to reconstruct rather optimistically comes again to the fore. This is particularly true for the first five lines, but effectively for all the text up to line 9. A statement like "Lines 2-9 clearly represent a version of 3:6-10 without 3:2b-5" (49) seems bold to say the least. Still, I concur with Elgvin that 4QCant ${ }^{\mathrm{b}}$ quite probably had a shorter text than MT, but I would not be so confident when it comes to the possibilities for a reconstruction. Also, his conclusion that "shorter" points to an "earlier recension" (50) might be a little bit hasty. As fascinating as his combination of the methods of textual and literary criticism is (he often draws upon Heinevetter), it might have been more precise to apply them separately.

The main divergences vis-à-vis Tov in Col. III pertain to the beginning of the column, while the rest is mostly the same. According to Elgvin, Col. III sets in with Song 4:1b (i. e. with no additional line above Tov's and Puech's line 2), which seems convincing given the new photographic material. Also, he explains the scribal error in line 11 (his count) more fitting to the evidence in the manuscript than Tov.

Some of Elgvin's reconstructions in Col. II might, once more, appear rather optimistic (e. g. latter half of line 1, ends of lines 2, 5, and 10). Furthermore, most proposed variant readings are again to be found on the fringes. Still, it should be noted that the shorter text in line 7 vis-à-vis MT Song 4:8 is actually one of the few instances in which one of Elgvin's variant readings is given clearly and unambiguously, and not only somewhere beyond the readable text.

The bold approach can be perceived again in Col. IV (which in substance confirms the prior reading by Tov). Calling his reconstruction "tentative" (60), his textual proposal for lines 1-4 (in which nothing much is preserved) rests solely on some traces in line 4. This pertains to lines 8 and 9, as well, albeit to a lesser extent. Also, he proposes a conjecture in Song 5:1, where he reads the appeal in singular forms: "[ Eat, my darling!, Drink ]" (60). This decision (see the comment on 61) is mainly justified by aesthetic reasoning and a reference to the Peshitta (which actually reads a plural). One important insight, however, is that the intriguing scribal sign below the last line of Col. IV (see Tov's reconstruction) is simply not there, as Elgvin demonstrates and as can be verified by the photographic material. 
The fragment of $4 \mathrm{QCant}{ }^{\mathrm{c}}$ is dated to the beginning of the $1^{\text {st }}$ century CE, and its reconstruction again more or less confirms Tov's assessment. The main and compelling new insight is that the lower of the two preserved lines might have constituted the last line of the column with the bottom margin below.

Elgvin's new edition of 6QCant, "written in a beautiful late Herodian hand" (70), is very welcome as the original one stems from 1962. Even though Elgvin confirms most of the prior edition by Baillet, he is frequently more precise in several details and, at the same time, positively more courageous in his reconstructions. The most important lessons are: In Col. I, Elgvin identifies several discernable letters (e. g. in lines 4, 5, and 6) not included in the original edition, as well as a supercolumnar title. Elgvin concludes from the latter that the Song was not considered "biblical," pointing to an observation by Tov that only non-biblical books exhibit such titles. While this is certainly a possible explanation, it presupposes a clear distinction of "biblical" and "non-biblical" at the time. At the beginning of Col. I line 3, Elgvin shows that Baillet's reading is not feasible (although his own reconstruction requires a scribal error). As a consequence, 6QCant probably exhibits a text differing from MT. However, with the scantly preserved surface it is almost impossible to ascertain the original text of the manuscript. Based on another variant reading in Col. I line 5, Elgvin offers an interesting interpretation for the notoriously difficult מישרים-phrase in Song 1:4. He reads מִיְשׁׁרים אהובים ("they are loved by the righteous", 76), probably taking the as deriving from מן (without explicitly saying so).

Somewhat puzzling is a statement that the letter preceding הביא in line 4 (Song 1:4) cannot be a (72), as this is not corroborated by the online photographs and as Elgvin still

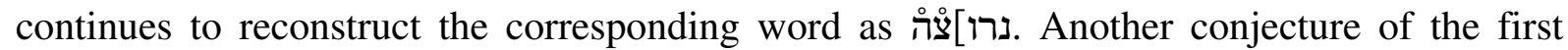
word in Song 1:3, is not quite relatable, as well, as there is no evidence for this change in this manuscript, nor in any other witness.

In Col. II, Elgvin returns to his bold approach proposing a reading of three complete lines (in his count 5-7) on the basis of two at best marginally visible letters in line 7 . Likewise, the questions, if 6QCant actually contained the whole MT text, and whether the scroll might in fact belong to Murabba'at, Nahal Hever, or cave 11, as Elgvin suggests, can certainly be entertained, but not decided.

In chapter 2: No Small Difference, Elgvin goes/sifts through the variant readings again, only with more space dedicated to the comparison and discussion of the various recensions. $\mathrm{He}$ argues that many of the Qumran variants represent cases of lectio difficilior (not all of them equally convincing, as e.g. his reasoning about Song 2:14, and 7:4) or that the Aramaisms in $4 \mathrm{QCant}{ }^{\mathrm{b}}$ represent an 
earlier recension of the later "more polished" (88) MT. All this serves to substantiate his claim that the Qumran texts differ much more from the version contained in MT than prior interpretations suggested. While the differences vis-à-vis MT need indeed to be taken seriously, I am not fully convinced that they are as substantial as Elgvin recurrently maintains. The majority of his identified variants are in barely preserved sections of the manuscripts, while the body of the given texts is, overall, quite close to MT.

In chapter 3: The Canticles Scrolls and the Early Textual Tradition, the author proposes that the Qumran scrolls of the Song do not represent stages of textual transmission, but rather of literary growth. He sees the Song as "a large collection of smaller units and collections compiled and polished by editors well versed in earlier "biblical writings"" (96), "reaching its final form around the turn of the era," when "previous recensions were still circulating" (97). Most of the following chapters strive to corroborate this hypothesis by taking various approaches.

In chapter 4: Late Linguistic and Cultural Features, Elgvin draws upon observations by various scholars that, in his opinion, suggest many Hellenistic influences. He suggests the Tobiad court as "commensurable with the setting reflected in many of the songs" (108). While several linguistic details indeed point to Hellenistic times, one should remain cautious as these details only prove that the last redactional stage(s) adhered to a certain style of speech. On the other hand, Elgvin points out correctly that they occur throughout the song (contra Zakovitch). ${ }^{4}$ In fact, Elgvin himself argues that single words can easily be exchanged (and, to my mind, maybe even short phrases).

Toponyms, the Beloved Land, and the Hasmonean State in the Song are extensively discussed in chapter 5, concentrating especially on the places in the north (e.g. Hermon, Gilead, Bashan etc.), as well as Ein Gedi, and, in particular, Heshbon with its pools. He concludes that "[a]ll of the places have a "Hasmonean flavour" (117) and claims that they are in nearly every instance irreplaceable in their respective contexts. While the former statement seems rather convincing (at least in the cases pointed out by Elgvin), I have my doubts about the latter. Additionally, Elgvin glosses over two other issues: On the one hand, he describes Tirzah as "long-time ruined" (114), but offers no solution to the dating problems that go with the reference to the former capital of the Northern Kingdom that, in Hellenistic times, did no longer play any significant role whatsoever. On the other hand, he explains the mentions of far-away places like Damascus, Kedar, Egypt, or Lebanon only in passing or not at all. Many

\footnotetext{
${ }^{4}$ Y. Zakovitch, Das Hohelied, Herders Theologischer Kommentar zum Alten Testament (Freiburg i. Br.: Herder, 2004), 66 and 70.
} 
toponyms in the Song are, in my view, simply employed to convey exoticism. As a result, I am hesitant to put too much stress on historic Hasmonean rule over the areas as argued by Elgvin. Nevertheless, he is absolutely correct that Hellenistic influence on this book can hardly be underestimated.

Chapter 6: The Geographical and Cultural Setting of Canticles adds to the observations of the preceding chapter while referencing various archaeological findings, especially by Finkelstein and Ben-Ami (somewhat digressing from the focus on the Song). He interprets the Towers of David (Song 4:4) and Lebanon (Song 7:5) as parts of Hasmonean fortifications in Jerusalem, which is quite possible, but, especially in the latter case, difficult to verify. Furthermore, he indicates that Jerusalem was surrounded by agricultural villages at that time, which would be the basis for the countryside imagery. Yet this feature is hardly unique to Hasmonean times. However, the basic idea that the Song of Songs was a sensual counter-voice to the more puritan Psalms of Solomon, is an appealing idea.

The diachronic line of reasoning is continued in chapter 7: Solomon and the Songs. Elgvin stresses that Solomon was very popular under Hasmonean reign, as demonstrated in recourse to various contemporary texts. Accordingly, that period is proposed as most fitting to the Song's "Solomonic flavur" (138, sic), and Solomon serves "as the ideal and typos for the present ruling dynasty" (143).

In chapter 8: Canticles as a Symbolic Text, Elgvin tackles the question as to whether the Song represents literal poetry about human love, or, rather, a metaphor for the relationship between God and Israel. By calling it a "symbolic text," Elgvin proposes that the Song is "characterized by multiple meanings, 'literal' (physical, real) and "metaphorical' dimensions existing simultaneously" (145). He argues that the original love songs could be read as religious literature against the background of other Biblical texts (e.g. Genesis, Exodus, Isaiah, or the Bundesformel, ${ }^{5}$ while still preserving the literal sense.

Chapter 9: The Literary Growth of Canticles - an Outline is dedicated to the details of his diachronic hypothesis. Here, Elgvin makes use of his textual critical observations, but also employs classical literary critical arguments (e. g. aesthetics, textual doublets, repetitions). He identifies five stages of growth: (A) Grundschrift: 2:9b-3:2a; 3:6.7-11*, and 4:1-7 (pre$4 \mathrm{QCant}^{\mathrm{b}, \mathrm{a}}$ ); (B) an earlier expansion witnessed in 4QCant ${ }^{\mathrm{b}}$ (adding Song 3:7-11*; 4:8-5:1); (C) a later expansion represented in 4QCant ${ }^{\mathrm{a}}$ (Song 2:3?-6; 3:2b-5; 6:11-7:7; 7:8-8:6?); both $\mathrm{B}$ and $\mathrm{C}$ are editorial stages of the late $1^{\text {st }}$ century BCE; (D) a hypothetical layer based on literary critical arguments (Song 1:5-2:2; 1:2-4; 2:7.8-9a; 5:2-6:10; 8:7.8-10) of the early first century $\mathrm{CE}$, the arguments concerning which could have been

\footnotetext{
${ }^{5}$ Cf. L. Schwienhorst-Schönberger, Das Hohelied der Liebe (Freiburg i. Br.: Herder, 2015).
} 
presented in greater detail; (E) a first century recension serving as precursor for 6QCant, LXX Vorlage, MT, Peshitta (Song 1:1; 8:11-12.13-14). The later stages supposedly put more stress on Solomon - Elgvin speaks of "Solomonic polishing" (163), and Solomonization. Also, they tend to soften the eroticism by "censorship" (162). For the redactional process as a whole, Elgvin points to other reworkings of biblical and non-biblical books as parallels, particularly to the book of Jubilees.

Chapter 10: Early Reception History still revolves around literary growth. For one, the author claims that there are no clear allusions to the Song in other biblical texts (contra other studies e. g. by K. J. Dell, or A. Schellenberg ${ }^{6}$ ). Then, he states that the referencing to the Song as an "inspired text" (181) takes up only in the first century CE, invoking examples from NT, and Rabbinic literature. Finally, the "atomistic"/"midrashic" (175) approach in these sources would be in line with a close proximity to the time of the final editing. Thus, Elgvin concludes that "the book only reached its 'canonical' form around the turn of the era, its authoritative status still being contested during the first half of the second century" (190).

In a short chapter on Small-Sized Scrolls of Lamentations, Ruth, and Canticles, Elgvin concludes that the Song obviously had a high significance and esteem; it might even have been some sort of "edifying texts around the turn of the era both within the Yahad and across broader circles of Judean society" (192) without getting too specific on the details.

Chapter 12: Conclusions presents a short round-up of the main theses. On the whole, the bottom line of this monograph is: "Canticles did not develop along a linear, diachronic path, the divergences between $4 \mathrm{QCant}{ }^{\mathrm{b}}$ and $4 \mathrm{QCant}^{\mathrm{a}}$ testifying to a complex process of growth during which various recensions circulated at the same time" (92). I fully agree with this assessment, as well as with the following that Elgvin's work "does not lead to any conclusions regarding ... the dependence of one witness upon another. We are presented with a pluriform textual tradition" (88). This, however, is somewhat at odds with his later model of literary growth. The question is: How helpful is it to actually speak of "earlier" or "later" recensions? In the process of growth, textual material was certainly added at some point and other material probably removed (maybe even some that has not come down to us). If we take Elgvin by his word,

\footnotetext{
${ }^{6}$ See K. J. Dell, "Does the Song of Songs have any connections to wisdom," in Perspectives on the Song of Songs, ed. A. C. Hagedorn (Berlin: de Gruyter, 2005), 24; or, more recently, A. Schellenberg, " May Her Breasts Satisfy You at All Times' (Prov 5:19): On the Erotic Passages in Proverbs and Sirach and the Question of How They Relate to the Song of Songs," VT 68 (2018), 252-271.
} 
however, we should maybe not consider a linear model of "Fortschreibung" (thus Elgvin 98), but rather the more dynamic concept of Zersingen, ${ }^{7}$ in which it is hard to tell apart one "branch of growth" from another because shorter and longer versions existed side-by-side and influenced one another. Only one of these would later become known as the Biblical Song of Songs, but if that was an "early" or "late" recension is hard to determine, especially in the case of the four Qumran scrolls. Admittedly, Elgvin's model of literary growth is certainly a well-conceived possibility, but it is only one among many explanations.

The volume contains 66 illustrative figures (several in color), and indices of modern authors, as well as ancient sources. An extra round of editing would have helped to root out the frequent spelling mistakes in English, German, Hebrew and Greek. In spite of this, Elgvin needs to be commended for his new and close reading of the Qumran manuscripts as well as for his inspiring push for a very late dating of the Song. Some of his decisions could be debated, yet, in future deliberations Elgvin's work must definitely be taken into account.

Hopf, Matthias

Faculty of Theology

University of Zurich

matthias.hopf@ theol.uzh.ch

\footnotetext{
${ }^{7}$ Zersingen is a dynamic form of multiple authorship, in which, through oral and written transmission, many variants exist simultaneously. For this concept see, e. g., M. Fox, The Song of Songs and the Ancient Egyptian Love Songs (Madison: University of Wisconsin Press, 1985), 222-224.
} 